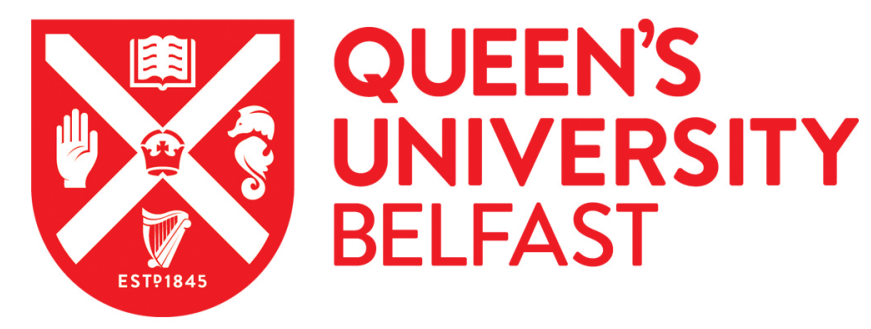

\title{
The effect of high polyphenol oxidase grass silage on metabolism of polyunsaturated fatty acids and nitrogen across the rumen of beef
} steers

Lee, M. R. F., Theobald, V. J., Gordon, N., Leyland, M., Tweed, J. K. S., Fychan, R., \& Scollan, N. D. (2014). The effect of high polyphenol oxidase grass silage on metabolism of polyunsaturated fatty acids and nitrogen across the rumen of beef steers. Journal of Animal Science, 92(11), 5076-5087.

https://doi.org/10.2527/jas.2014-7812

Published in:

Journal of Animal Science

Document Version:

Publisher's PDF, also known as Version of record

Queen's University Belfast - Research Portal:

Link to publication record in Queen's University Belfast Research Portal

\section{Publisher rights}

Copyright 2014 American Society of Animal Science.

This work is made available online in accordance with the publisher's policies. Please refer to any applicable terms of use of the publisher.

\section{General rights}

Copyright for the publications made accessible via the Queen's University Belfast Research Portal is retained by the author(s) and / or other copyright owners and it is a condition of accessing these publications that users recognise and abide by the legal requirements associated with these rights.

\section{Take down policy}

The Research Portal is Queen's institutional repository that provides access to Queen's research output. Every effort has been made to ensure that content in the Research Portal does not infringe any person's rights, or applicable UK laws. If you discover content in the

Research Portal that you believe breaches copyright or violates any law, please contact openaccess@qub.ac.uk. 


\title{
The effect of high polyphenol oxidase grass silage on metabolism of polyunsaturated fatty acids and nitrogen across the rumen of beef steers $^{1}$
}

\author{
M. R. F. Lee, ${ }^{2,3}$ V. J. Theobald, N. Gordon, M. Leyland, J. K. S. Tweed, R. Fychan, and N. D. Scollan \\ Institute of Biological, Environmental and Rural Science, \\ Aberystwyth University, Gogerddan Campus, Aberystwyth, Ceredigion, SY23 3EB, UK
}

\begin{abstract}
Polyphenol oxidase (PPO) activity in red clover (Trifolium pratense) has been reported to reduce both proteolysis and lipolysis, resulting in greater $\mathrm{N}$ use efficiency and protection of PUFA across the rumen. Although high levels of PPO have been reported in grasses such as cocksfoot (orchard grass; Dactylis glomerata), no in vivo research has determined whether grass PPO elicits the same response as red clover PPO. To test the hypothesis that silage ensiled from grass with high levels of PPO protects N and PUFA across the rumen, 6 steers with ruminal and duodenal cannulas were offered cocksfoot silage (CO; high-PPO grass), perennial ryegrass silage (PR; Lolium perenne; low-PPO grass), or red clover silage (RC; high-PPO control) at $16 \mathrm{~g} \mathrm{DM} /$ $\mathrm{kg}$ BW daily with the experiment consisting of two $3 \times$ 3 Latin squares with 21-d periods, consisting of $12 \mathrm{~d}$ of diet adaptation, $6 \mathrm{~d}$ of duodenal marker infusion, $2 \mathrm{~d}$ of duodenal sampling, and $1 \mathrm{~d}$ of ruminal sampling. All silages were well preserved, with DM of 34.4, 55.3, and $45.4 \%$ for $\mathrm{CO}, \mathrm{PR}$, and RC. Activity of PPO in silages
\end{abstract}

was low due to deactivation but was greater in $\mathrm{CO}$ than either PR or RC ( 0.15 vs. 0.05 and $0.08 \mu \mathrm{katal} / \mathrm{g} \mathrm{DM})$. Protein-bound phenol (mg/g DM) as a measure of the degree of oxidation and an indication of PPO protection was greatest for RC (15.9) but comparable for PR (10.1) and CO (12.2). Biohydrogenation of C18 PUFA was significantly lower on $\mathrm{RC}$ compared to the 2 grass silages with CO greater than PR. Despite lower levels of total fatty acid intake and subsequent duodenal flow, $\mathrm{CO}$ resulted in greater levels of phytanic acid and total branched and odd chain fatty acids in duodenal digesta than RC or PR. Ruminal ammonia concentration was greatest for $\mathrm{RC}$, with no difference between the grasses. Duodenal flow of microbial $\mathrm{N}$ and efficiency of microbial protein synthesis were lowest for $\mathrm{CO}$ and comparable for $\mathrm{RC}$ and $\mathrm{PR}$. The CO (high-grass PPO) did not result in elevated levels of C18 PUFA escaping the rumen or improve efficiency of total $\mathrm{N}$ transfer through the rumen compared to PR. The $\mathrm{RC}$ resulted in a greater flow of $\mathrm{N}$ and nonmicrobial $\mathrm{N}$ to the duodenum than the 2 grasses with PR greater than CO.

Key words: beef steers, cocksfoot silage, nitrogen metabolism, polyphenol oxidase, polyunsaturated fatty acids

\section{INTRODUCTION}

\footnotetext{
${ }^{1}$ The authors would like to acknowledge and thank Sue Lister and Delma Jones for the help analyzing the samples. This work was funded jointly by the UK Department for the Environment, Food and Rural Affairs, the English Beef and Lamb Executive, Quality Meat Scotland, and Hybu Cig Cymru within the project ProBeef.

${ }^{2}$ Present address: School of Veterinary Sciences, University of Bristol, Langford, Somerset, BS40 5DU, UK and Rothamsted Research North Wyke, Okehampton, Devon, EX20 2SB, UK.

${ }^{3}$ Corresponding author: michaelrf.lee@bristol.ac.uk

Received March 11, 2014.

Accepted August 30, 2014.
}

The group of enzymes collectively known as polyphenol oxidase (PPO) has been associated predominately with the detrimental effect of browning fruit and vegetables (Mayer, 2006). However, interest in PPO within forage crops has grown since the browning reaction was associated with reduced $\mathrm{N}$ losses in silo (Albrecht and Muck, 1991) and the rumen (Albrecht and Broderick, 1992). Subsequently, a red clover (Trifolium pratense) extract was shown to inhibit proteolysis by denaturing proteases (Jones et al., 1995). The reduction in protein breakdown in silo resulted in over $80 \%$ being 
retained as true protein, improving efficiency of $\mathrm{N}$ use (Broderick et al., 2001). A further benefit of red clover silage is a reduction in C18 PUFA biohydrogenation compared to grass silage (Lee et al., 2003). Polyphenol oxidase reduces plant mediated lipolysis (Lee et al., 2004) by inhibiting plant lipases (Van Ranst et al., 2011).

The potential to exploit PPO has led to transgenic approaches to introduce PPO into agriculturally important crops such as alfalfa (Medicago sativa; Sullivan et al., 2004). Lee et al. (2006b) screened 6 grass species for PPO activity and noted activity in cocksfoot (Dactylis glomerata) comparable to red clover. They also showed in vitro that grass PPO resulted in a reduction in plantmediated proteolysis and lipolysis similar to that previously observed in red clover. An in vitro investigation using the rumen simulation technique (Lee et al., 2011) indicated that cocksfoot resulted in lower proteolysis and a trend towards lower levels of lipolysis in vitro than a grass with a lower PPO content. However, it is yet to be determined whether grass with high levels of PPO has any effect on dietary protein and C18 PUFA in vivo. This study investigated the effect of 2 grass silages with contrasting levels of PPO (cocksfoot [high PPO] and perennial ryegrass [Lolium perenne; low $\mathrm{PPO}]$ ) and red clover on PUFA biohydrogenation and dietary N metabolism across the rumen of beef steers.

\section{MATERIALS AND METHODS}

All animal procedures and the care for the animals were performed under strict regulations described in the Animals (Scientific Procedures) Act 1986 issued by the Home Office of Her Majesty's Britannic Government.

\section{Experimental Design}

Six Hereford $\times$ Friesian steers $(415 \pm 23.1 \mathrm{~kg})$, prepared with a ruminal cannula and a simple "T"-piece cannula in the proximal duodenum (immediately after the pylorus and before the common bile duct; Jarrett, 1948), were allocated to either red clover silage (RC), cocksfoot silage (CO), or perennial ryegrass silage (PR). The silages were offered at a daily rate of $16 \mathrm{~g} \mathrm{DM} / \mathrm{kg} \mathrm{BW}$ to each animal. The experiment consisted of two $3 \times 3$ Latin squares with each period $21 \mathrm{~d}$ in duration, consisting of $12 \mathrm{~d}$ of adaptation to the diet, $6 \mathrm{~d}$ for duodenal marker infusion, $2 \mathrm{~d}$ for duodenal sampling, and $1 \mathrm{~d}$ for ruminal sampling.

Animals were weighed before allocation to treatment and at the end of each period, with BW used to determine feed offered for each steer during the subsequent period. Silage DM was determined at each mixing of the big bales to provide silage for each period. Daily feed allocations were offered in 2 equal meals at 0800 and 1600 $\mathrm{h}$. Any refusals were removed at $0745 \mathrm{~h}$ and subsampled so that actual DMI could be determined. Animals were individually penned and had free access to fresh water and mineral blocks: Mg, 5,000 mg/kg; Fe, 1,500 mg/kg; Co, $50 \mathrm{mg} / \mathrm{kg}$; $\mathrm{Cu}, 300 \mathrm{mg} / \mathrm{kg}$; I, $150 \mathrm{mg} / \mathrm{kg}$; Mn, $200 \mathrm{mg} / \mathrm{kg}$; $\mathrm{Zn}, 300 \mathrm{mg} / \mathrm{kg}$; Se, $10 \mathrm{mg} / \mathrm{kg}$; and $\mathrm{Na}, 380 \mathrm{~g} / \mathrm{kg}$ (Baby Red Rockies; Winsford, Cheshire, UK).

Red clover (cv. Milvus; 1.3 ha) was sown at a rate of $17 \mathrm{~kg} /$ ha on August 10, 2007; cocksfoot (cv. AberTop; $1.2 \mathrm{ha}$ ) at $27 \mathrm{~kg} / \mathrm{ha}$ on August 13, 2007; and perennial ryegrass at $32 \mathrm{~kg} / \mathrm{ha}$ on August 13, 2007 (cv. AberStar; 1.2 ha), at Gaerwen, Bow Street, Aberystwyth, UK. Fertilizer as $60 \mathrm{~kg} \mathrm{P}_{2} \mathrm{O}_{5} /$ ha and $60 \mathrm{~kg} \mathrm{~K}_{2} \mathrm{O} /$ ha was applied to all plots and $43 \mathrm{~kg} \mathrm{NH}_{4} \mathrm{NO}_{3} /$ ha was applied to the grass plots in August 2007 and subsequently in May 2008 and 2009. In 2007, swards were maintained through rotationally grazing with sheep. In 2008, 2 silage cuts were taken (May and July) and swards maintained in the autumn and winter through sheep grazing. In February 2009, the red clover was treated with Kerb herbicide (Dow Agrosystems, Hitchin, Herts, UK) to control grass weeds, and in April 2009 both grass swards were sprayed with a broad leaf herbicide (Cimarron, DuPont, Wilmington, DE, USA). All forage were harvested on July 6, 2009, as a second cut, $6 \mathrm{wk}$ after the first cut, using a Vicon crimper mower (Kverneland, Stavanger, Norway) and left in swaths for $48 \mathrm{~h}$. The herbage was unchopped and treated with Live System biological additive Powerstart at a rate of $2 \mathrm{~L} / \mathrm{t}$ fresh weight to supply approximately $1 \times 10^{12} \mathrm{cfu}$ (Genus Plc, Crewe, Cheshire, UK) during baling. Big bales were produced using 8 layers of 750 -mm-wide $25-\mu \mathrm{m}$ film wrap and stored on farm until first opening in February 2010.

\section{Sample Collection Methods}

A representative silage sample of each forage per period was collected by subsampling (approximately $200 \mathrm{~g}$ fresh weight) daily and bulking per period and was maintained frozen at $-20^{\circ} \mathrm{C}$ before analysis.

Digesta flow at the duodenum was estimated using a dual-phase marker system with ytterbium acetate and chromium EDTA as the particulate and liquid phase markers, respectively (Faichney, 1975). On d 12 of each period, duodenal background samples $(250 \mathrm{~mL})$ were collected and a whole and centrifuged (3,000 x g for $25 \mathrm{~min}$, $4^{\circ} \mathrm{C}$ ) digesta sample were prepared as described by Merry et al. (2006). These were frozen at $-20^{\circ} \mathrm{C}$ before being lyophilized and analyzed. On d 13, ytterbium acetate $(489 \pm 32 \mathrm{mg} / \mathrm{L})$ and chromium EDTA $(3,356 \pm 75 \mathrm{mg} / \mathrm{L}$ infusions commenced via the ruminal cannula at a rate of $25.7 \pm 0.51$ and $26.5 \pm 0.35 \mathrm{~mL} / \mathrm{h}$, respectively. At the same time, to speed the attainment of plateau, a $200-\mathrm{mL}$ dose of ytterbium acetate and chromium EDTA was manually poured into the rumen via the ruminal cannula of 
each steer. Duodenal digesta ( $250 \mathrm{~mL}$ at each collection) was manually collected on d 19 and 20, every 3-h interval over each 24-h period (i.e., 0, 3, 6, 9, 12, 15, 18, and $21 \mathrm{~h}$ and $1,4,7,10,13,16,19$, and $22 \mathrm{~h}$ ). To the collected sample, $1 \mathrm{~mL}$ of $0.5 \%$ butylated hydroxytoluene (BHT; $5 \mathrm{~g}$ BHT/L ethanol) was added, and the sample was bulked across the day and stored at $4{ }^{\circ} \mathrm{C}$ before preparation of a whole and centrifuged $\left(3,000 \mathrm{xg}\right.$ for $\left.25 \mathrm{~min}, 4^{\circ} \mathrm{C}\right)$ sample as described above. A separate duodenal microbial fraction for analysis of purine and pyrimidine as markers was obtained as described by Lee et al. (2002), lyophilized, and stored at $-20^{\circ} \mathrm{C}$ before analysis. Hourly ruminal fluid $(10 \mathrm{~mL}$ ) was collected on d 21 (from 0800 to $1700 \mathrm{~h}$ ); $\mathrm{pH}$ was determined immediately using a Hydrus $400 \mathrm{pH}$ probe (Fisher Scientific UK, Loughborough, Leicestershire, UK). A $1-\mathrm{mL}$ subsample was acidified with $100 \mu \mathrm{L}$ of $2.5 \mathrm{M}$ sulfuric acid and stored at $-20^{\circ} \mathrm{C}$ before analysis for VFA and ammonia-N concentrations.

\section{Chemical Analysis}

Water-soluble carbohydrate (WSC) of the silages was determined spectrophotometrically using anthrone in sulfuric acid on a Technicon Autoanalyzer (Technicon Corporation, Tarrytown, NY; Thomas, 1977). Ash and by-mass difference $\mathrm{OM}$ were analyzed by combusting the ground samples at $550^{\circ} \mathrm{C}$ for $6 \mathrm{~h}$ in a muffle furnace. The VFA in the ruminal digesta and silages were determined by GLC using Chrompack CP 9002 (CP-Sil 5CB column $10 \mathrm{~m} \times 0.25 \mathrm{~mm}$ i.d.; Varian Inc., Palo Alto, CA) following the method of Zhu et al. (1996). Ammonia-N was assessed enzymatically using glutamate dehydrogenase on a discrete analyzer (FP-901M Chemistry Analyzer; Labsystems Oy, Helsinki, Finland; and test kit number 6650; Sigma-Aldrich Co. Ltd., Poole, Dorset, UK). Nitrogen was determined by a micro-Kjeldahl technique using "Kjeltec" equipment (Perstorp Analytical Ltd., Maidenhead, Berkshire, UK). Neutral detergent fiber was determined as described by Van Soest et al. (1991), and ADF was analyzed according to the method of Van Soest and Wine (1967) using the Tecator Fibretec System equipment (Tecator Ltd., Thornbury, Bristol, Somerset, UK).

Chromium and ytterbium concentrations of digesta and infusate solutions were prepared as described by Williams et al. (1962) and analyzed using a Pye Unicorn SP9 Atomic Absorption Spectrophotometer (Spectronic Unicam, Cambridge, Cambridgeshire, UK). Concentrations of purine and pyrimidine bases were determined by HPLC (Cozzi et al., 1993).

Amino acids were determined by HPLC after acid hydrolysis by Alta Bioscience (University of Birmingham, West Midlands, UK). Threonine and serine were corrected for loss (5 and 10\%, respectively), whereas tryptophan and cysteine have been omitted due to degradation during acid hydrolysis. Fatty acids in silage were extracted and methylated from $0.5 \mathrm{~g}$ of freeze-dried sample suspended in 2 $\mathrm{mL}$ of toluene containing $0.4 \mathrm{mg} / \mathrm{mL} \mathrm{C} 23: 0$ as an internal standard. The methylation mixture and conditions consisted of $3 \mathrm{~mL}$ of a mixture of freshly made acetyl chloride to 10 parts anhydrous methanol at $70^{\circ} \mathrm{C}$ for $2 \mathrm{~h}$ (Sukhija and Palmquist, 1988). Fatty acids in digesta were converted to fatty acid methyl esters (FAME) with an internal standard $(100 \mu \mathrm{L} \mathrm{C} 21: 0 ; 15 \mathrm{mg} / \mathrm{mL})$ using a base-acid catalyzed transesterification procedure by incubation at $50^{\circ} \mathrm{C}$ with methanolic sodium hydroxide ( $0.5 \mathrm{M}$ sodium hydroxide in methanol; $15 \mathrm{~min}$ ) followed by incubation with methanolic hydrochloric acid $(5 \% \mathrm{HCl}$ in methanol; $1 \mathrm{~h})$ at $50^{\circ} \mathrm{C}$ and capturing in hexane (Kramer and Zhou, 2001). The FAME were analyzed by GLC on a CP-Select chemically bonded for FAME column (100 m by $0.25 \mathrm{~mm}$ i.d.; Varian Inc.) with split injection (30:1) and $\mathrm{He}$ as the carrier gas with oven conditions and run time as described by Lee et al. (2005). Identification of fatty acids was performed using external standards (ME61; Larodan Fine Chemicals, Malmo, Sweden; S37; Supelco, Poole, Dorset, UK; and CLA; Matreya, Philadelphia, PA) and quantified using the internal standard (C23:0 for silage or $\mathrm{C} 21: 0$ for digesta).

For the PPO activity, silage was extracted according to the method of Winters and Minchin (2001) and assayed according to the method of Robert et al. (1995). In brief, silage (approximately $0.5 \mathrm{~g}$ fresh weight) was ground in liquid $\mathrm{N}_{2}$ before extracting in $2 \mathrm{~mL}$ of cooled McIlvaine buffer $\left(4^{\circ} \mathrm{C}, \mathrm{pH}\right.$ 7.0; $0.1 \mathrm{M}$ citric acid:0.2 $\mathrm{M}$ sodium hydrogen phosphate; 17.6:82.4 vol/vol; McIlvaine, 1921) containing $0.1 \mathrm{M}$ ascorbate to prevent oxidation of endogenous substrates by PPO activity. Extracts were centrifuged at $15,000 \times g$ for $10 \mathrm{~min}$ at $4^{\circ} \mathrm{C}$ and the supernatant was retained. Supernatants were desalted by applying to columns (1.5 by $6 \mathrm{~cm})$ containing bio-Gel P6DG (Biorad, Hertfordshire, UK) prepared in McIlvaine buffer and centrifuging at 2,500 $\times g$ for $6 \mathrm{~min}$ at $4^{\circ} \mathrm{C}$. The PPO content was determined spectrophotometrically at $420 \mathrm{~nm}$ using $10 \mu \mathrm{L}$ of eluted fraction with $15 \mu \mathrm{L} 0.001$ $\mathrm{m} M$ copper sulfate, $10 \mathrm{~m} M$ methylcatechol, and $1.5 \mathrm{~mL}$ of Mcllvaine buffer containing $0.25 \%$ sodium dodecylsulfate. Enzyme reaction rate was defined as the amount of enzyme per gram of DM that produced $1 \mu \mathrm{mol}$ of quinone $/ \mathrm{s}(\mu \mathrm{katal} / \mathrm{g} \mathrm{DM})$ based on the absorption at 420 $\mathrm{nm}$ of a known concentration of quinones formed through the reaction of methylcatechol and sodium periodate (Adler and Magnusson, 1959) giving a conversion factor of $\mu \mathrm{katal}=(0.0453 \times \Delta$ optical density $)$. Protein-bound phenol (PBP) formation was assessed using a modified Lowry procedure described by Winters and Minchin (2005), which takes into account the response of diphenols with the Lowry assay and quantifies the PBP. 


\section{Calculations and Statistical Analysis}

Digesta flows were calculated after mathematical reconstitution of true digesta as described by Faichney (1975) after taking into account background levels of chromium and ytterbium. The reconstitution correction factors $(R)$ for each animal ranged between -0.1 to +0.1 , which indicated a representative estimation of duodenal flow from the dual-phase markers. Ruminal $\mathrm{pH}$, ammonia- $\mathrm{N}$, and VFA concentrations were analyzed using a repeated measure ANOVA (Genstat release 13.2 [PC/Windows Vista], Harpendon, Herts, UK) with diet as the treatment effect, blocking according to period plus animal, and hourly sample as the repeated measure. Time and the time $\times$ treatment interaction were found to be highly significant for all variables $(P<0.001)$. Treatment $P$-values were more varied and are reported along with SED of the treatment effect. Biohydrogenation of C18 PUFA was assessed as the difference between daily intake and duodenal flow $(\mathrm{g} / \mathrm{d})$ as a proportion of daily intake. Data were subjected to a general ANOVA (Genstat release 13.2 [PC/Windows Vista]) with diet as the treatment effect and blocking according to period plus animal. Tukey's honest significant difference test was used after ANOVA with significance stated at the $P<0.05$ level whereas a trend was defined as $P<0.1$.

\section{RESULTS}

\section{Silage Composition}

The 3 experimental silages had highly contrasting chemical compositions (Table 1). Dry matter and WSC were greater in PR followed by RC and lowest in CO. Organic matter was also greatest in $\mathrm{PR}$ but with $\mathrm{CO}$ greater than RC. The RC had the greatest total N and PBP and the lowest $\mathrm{pH}$ and fermentation acids with $\mathrm{PR}$ and $\mathrm{CO}$ similar for these parameters. Fiber content was greatest for $\mathrm{CO}$ followed by PR and lowest in RC. Activity of PPO and ammonia-N concentration were also greatest for $\mathrm{CO}$ but similar for PR and RC. Individual and total fatty acid and AA compositions are provided in Table 2. The C14:0, C16:0, C18:0, C18:2n-6, C18:3n-3, and total fatty acids were greatest in RC followed by PR and lowest in $\mathrm{CO}$. The CO was greatest in $\mathrm{C} 20: 0$ and total branched and odd chain (BOC) fatty acids followed by RC, with PR lowest. All individual and total AA with the exception of methionine followed the pattern of greatest concentration in $\mathrm{RC}$ followed by PR followed by CO. For methionine, PR had the greatest concentration followed by $\mathrm{CO}$ and $\mathrm{RC}$.

\section{Intake, Duodenal Flow of Fatty Acids, and $\mathrm{OM}$ Digestibility}

Dry matter intake was greatest for $\mathrm{RC}$ followed by PR and lowest with CO (Table 3). The C16:0, C18:0,
Table 1. Chemical composition, polyphenol oxidase (PPO) activity, and protein-bound phenol concentrations in the silages ( $\mathrm{g} / \mathrm{kg}$ DM unless stated)

\begin{tabular}{lcccc}
\hline \hline Item & $\mathrm{CO}^{1}$ & $\mathrm{PR}^{1}$ & $\mathrm{RC}^{1}$ & $\mathrm{SED}$ \\
\hline $\mathrm{DM}, \mathrm{g} / \mathrm{kg}$ as is & 341 & 555 & 449 & 18.5 \\
$\mathrm{OM}$ & 918 & 927 & 909 & 2.8 \\
Water-soluble carbohydrate & 15.4 & 99.1 & 48.7 & 4.63 \\
Total N & 19.2 & 20.1 & 26.3 & 0.69 \\
$\mathrm{NDF}$ & 603 & 525 & 378 & 6.9 \\
$\mathrm{ADF}$ & 357 & 281 & 266 & 6.9 \\
PPO activity, $\mu \mathrm{katal} / \mathrm{g} \mathrm{DM}$ & 0.15 & 0.05 & 0.08 & 0.016 \\
Protein-bound phenol & 12.2 & 10.1 & 15.9 & 0.95 \\
pH & 4.58 & 4.72 & 4.23 & 0.088 \\
Acetate & 10.5 & 11.5 & 4.0 & 2.78 \\
Propionate & 0.86 & 0.14 & 0.09 & 0.182 \\
$n$-Butyrate & 0.88 & 0.09 & 0.10 & 0.133 \\
$i$-Butyrate & 0.07 & 0.03 & 0.17 & 0.090 \\
$i$-Valerate & 0.03 & 0.02 & $\mathrm{ND}^{2}$ & 0.019 \\
Ammonia-N & 2.76 & 1.54 & 1.81 & 0.192 \\
\hline
\end{tabular}

${ }^{1} \mathrm{CO}=$ cocksfoot silage; $\mathrm{PR}=$ perennial ryegrass silage; $\mathrm{RC}=$ red clover silage. ${ }^{2} \mathrm{ND}=$ not detectable.

C18:2n-6, and total fatty acids followed the same pattern as DMI. C14:0, C18:1n-9, and C18:3n-3 showed patterns of intake similar to DM but with RC and PR comparable for all fatty acids and $\mathrm{CO}$ and $\mathrm{PR}$ also comparable for C14:0. The CO had the greatest intake of C20:0 and BOC fatty acids followed by RC and was lowest in PR, although for BOC fatty acids, PR and RC were not different. Duodenal flow of DM followed the same pattern as DMI with RC > PR > CO. Duodenal flows of C16:0, C18:2 nonconjugated dienes (except C18:2n-6), C18:2n-6, and C18:3n-3 followed the same pattern as DM flow. Duodenal flow of C18:1 cis, CLA, and total fatty acids were greatest on RC with no difference between the 2 grasses. For C12:0 and C18:1 trans, $\mathrm{CO}$ had the lowest duodenal flow with no difference between RC and PR. The greatest duodenal flow of phytanic acid and BOC fatty acids was observed for $\mathrm{CO}$ followed by PR with $\mathrm{RC}$ the lowest. There were no differences in flow of C14:0, C16:1n-7, and $\mathrm{C} 18: 0$ among the silage treatments.

The proportions of the individual C18:1 isomers found in the duodenal digesta are reported in Table 4. cis9 and trans-11 were the greatest cis and trans isomers on all silage diets, making up on average 73.4 and $58.2 \%$ of all cis and trans isomers, respectively. However, the range of the different isomers, specifically between $\mathrm{CO}$ and $\mathrm{PR} /$ $\mathrm{RC}$ for cis and between RC and the 2 grasses for trans, were different. For cis-9, cis-11, and cis-15, CO was significantly lower than RC, with PR greatest for $c i s-11$ and not different than RC for cis-9 and not different from $\mathrm{CO}$ for cis-15. There was no difference in the proportions of cis-13, averaging $0.95 \%$ of total cis across all silage diets. Likewise, there were no differences in the proportions of trans-4, trans-5, trans-6/7/8 (combined peak), and trans-9, 
Table 2. Fatty acid and AA compositions ( $/ \mathrm{kg} \mathrm{DM})$ of the dietary silages

\begin{tabular}{|c|c|c|c|c|}
\hline Item & $\mathrm{CO}^{1}$ & $\mathrm{PR}^{1}$ & $\mathrm{RC}^{1}$ & SED \\
\hline \multicolumn{5}{|l|}{ Fatty acids } \\
\hline C12:0 & 0.11 & 0.11 & 0.05 & 0.006 \\
\hline $\mathrm{C} 14: 0$ & 0.14 & 0.15 & 0.18 & 0.015 \\
\hline C16:0 & 2.85 & 3.51 & 3.84 & 0.076 \\
\hline $\mathrm{C} 16: 1 n-7$ & 0.040 & 0.064 & 0.035 & 0.0046 \\
\hline Phytanic acid & 0.034 & 0.018 & 0.015 & 0.0041 \\
\hline $\mathrm{C} 18: 0$ & 0.26 & 0.39 & 0.55 & 0.018 \\
\hline $\mathrm{C} 18: 1 n-9$ & 0.30 & 0.48 & 0.43 & 0.014 \\
\hline $\mathrm{C} 18: 2 n-6$ & 2.87 & 3.15 & 4.35 & 0.075 \\
\hline C18:3n-3 & 7.50 & 8.22 & 7.93 & 0.256 \\
\hline C20:0 & 0.31 & 0.16 & 0.21 & 0.011 \\
\hline BOC fatty acids ${ }^{2}$ & 0.52 & 0.31 & 0.41 & 0.013 \\
\hline Total & 16.0 & 18.0 & 19.3 & 0.46 \\
\hline \multicolumn{5}{|l|}{$\mathrm{AA}$} \\
\hline Aspartic acid & 5.06 & 7.64 & 14.00 & 0.385 \\
\hline Threonine & 2.89 & 3.91 & 5.17 & 0.164 \\
\hline Serine & 1.93 & 3.43 & 5.06 & 0.381 \\
\hline Glutamic acid & 4.42 & 5.79 & 9.86 & 0.361 \\
\hline Proline & 4.35 & 5.12 & 7.71 & 0.126 \\
\hline Glycine & 3.47 & 4.06 & 5.02 & 0.151 \\
\hline Alanine & 5.46 & 5.60 & 6.24 & 0.153 \\
\hline Valine & 4.37 & 4.90 & 6.65 & 0.170 \\
\hline Methionine & 0.78 & 1.36 & 0.54 & 0.135 \\
\hline Isoleucine & 3.52 & 3.95 & 5.60 & 0.140 \\
\hline Leucine & 5.95 & 6.79 & 9.22 & 0.283 \\
\hline Tyrosine & 1.37 & 2.38 & 3.62 & 0.152 \\
\hline Phenylalanine & 3.81 & 4.51 & 5.97 & 0.245 \\
\hline Histidine & 1.27 & 1.64 & 2.44 & 0.080 \\
\hline Lysine & 2.94 & 4.46 & 6.63 & 0.578 \\
\hline Arginine & 1.82 & 3.67 & 5.46 & 0.246 \\
\hline Total & 53.4 & 69.2 & 99.2 & 2.90 \\
\hline
\end{tabular}

averaging $0.30,0.28,3.69$, and $2.37 \%$ of total trans, respectively. trans-11 was significantly lower as a proportion of total trans in RC compared to both $\mathrm{CO}$ and PR, with the opposite true for trans-10, trans-12, trans-13/14, trans-15, and trans-16.

Organic matter apparently and truly digested in the rumen was lower for RC than the 2 grasses, with no difference between PR and CO (Table 3).

\section{Ruminal Parameters}

Biohydrogenation of C18 PUFA was lower with RC than the 2 grass silages and lower with PR compared to $\mathrm{CO}$ (Table 5). Mean ruminal $\mathrm{pH}$ was greatest for $\mathrm{CO}$ followed by RC and lowest for PR (Table 5). Temporal changes in ruminal $\mathrm{pH}$ are shown in Fig. 1a. On all silage diets, there was a drop in ruminal $\mathrm{pH}$ after the $0800 \mathrm{~h}$ feeding, although this was more pronounced with $\mathrm{RC}$ than the grass silage diets. Throughout the day to the next feeding at $1600 \mathrm{~h}$, there was a rise in $\mathrm{pH}$ for the $\mathrm{RC}$-fed animals so that by $1500 \mathrm{~h}$, $\mathrm{pH}$ for $\mathrm{RC}$ was greater than either $\mathrm{CO}$ or PR. For both $\mathrm{CO}$
Table 3. Intake and duodenal flow of DM and fatty acids in steers fed the 3 silage diets

\begin{tabular}{|c|c|c|c|c|c|}
\hline Item & $\overline{\mathrm{CO}^{1}}$ & $\mathrm{PR}^{1}$ & $\overline{\mathrm{RC}^{1}}$ & SED & $P$-value \\
\hline \multicolumn{6}{|l|}{ Intake } \\
\hline $\mathrm{DM}, \mathrm{kg} / \mathrm{d}$ & $5.87^{\mathrm{a}}$ & $6.58^{\mathrm{b}}$ & $7.55^{\mathrm{c}}$ & 0.197 & $<0.001$ \\
\hline $\mathrm{OM}, \mathrm{kg} / \mathrm{d}$ & $5.39^{\mathrm{a}}$ & $6.10^{\mathrm{b}}$ & $6.85^{\mathrm{c}}$ & 0.177 & $<0.001$ \\
\hline \multicolumn{6}{|l|}{ Fatty acids, g/d } \\
\hline $\mathrm{C} 12: 0$ & $0.67^{\mathrm{b}}$ & $0.72^{\mathrm{b}}$ & $0.38^{\mathrm{a}}$ & 0.053 & $<0.001$ \\
\hline $\mathrm{C} 14: 0$ & $0.81^{\mathrm{a}}$ & $1.05^{\mathrm{ab}}$ & $1.26^{\mathrm{b}}$ & 0.103 & 0.008 \\
\hline $\mathrm{C} 16: 0$ & $16.5^{\mathrm{a}}$ & $23.4^{\mathrm{b}}$ & $28.7^{\mathrm{c}}$ & 0.94 & $<0.001$ \\
\hline $\mathrm{C} 16: 1 n-7$ & $0.22^{\mathrm{a}}$ & $0.41^{\mathrm{b}}$ & $0.25^{\mathrm{a}}$ & 0.011 & $<0.001$ \\
\hline C18:0 & $1.52^{\mathrm{a}}$ & $2.62^{\mathrm{b}}$ & $4.04^{\mathrm{c}}$ & 0.150 & $<0.001$ \\
\hline $\mathrm{C} 18: 1 n-9$ & $1.81^{\mathrm{a}}$ & $3.15^{\mathrm{b}}$ & $3.15^{\mathrm{b}}$ & 0.086 & $<0.001$ \\
\hline $\mathrm{C} 18: 2 n-6$ & $16.6^{\mathrm{a}}$ & $21.0^{\mathrm{b}}$ & $32.5^{\mathrm{c}}$ & 0.84 & $<0.001$ \\
\hline $\mathrm{C} 18: 3 n-3$ & $43.5^{\mathrm{a}}$ & $55.1^{\mathrm{b}}$ & $59.6^{\mathrm{b}}$ & 2.21 & $<0.001$ \\
\hline C20:0 & $1.80^{\mathrm{c}}$ & $1.01^{\mathrm{a}}$ & $1.53^{\mathrm{b}}$ & 0.083 & $<0.001$ \\
\hline $\mathrm{BOC}^{2}$ fatty acids & $2.64^{b}$ & $1.53^{\mathrm{a}}$ & $1.59^{\mathrm{a}}$ & 0.114 & $<0.001$ \\
\hline Total & $93.4^{\mathrm{a}}$ & $120^{\mathrm{b}}$ & $144^{\mathrm{c}}$ & 4.71 & $<0.001$ \\
\hline \multicolumn{6}{|l|}{ Duodenal flow } \\
\hline $\mathrm{DM}, \mathrm{kg} / \mathrm{d}$ & $4.47^{\mathrm{a}}$ & $5.11^{\mathrm{b}}$ & $5.80^{\mathrm{c}}$ & 0.219 & $<0.001$ \\
\hline $\mathrm{OM}, \mathrm{kg} / \mathrm{d}$ & $3.29^{\mathrm{a}}$ & $3.76^{\mathrm{b}}$ & $4.64^{\mathrm{c}}$ & 0.170 & $<0.001$ \\
\hline OMAD, ${ }^{3} \%$ & $38.9^{\mathrm{b}}$ & $38.6^{\mathrm{b}}$ & $32.4^{\mathrm{a}}$ & 1.73 & 0.009 \\
\hline OMTD, ${ }^{4} \%$ & $56.3^{\mathrm{b}}$ & $60.2^{\mathrm{b}}$ & $51.4^{\mathrm{a}}$ & 1.70 & 0.003 \\
\hline \multicolumn{6}{|l|}{ Fatty acids, g/d } \\
\hline $\mathrm{C} 12: 0$ & $0.30^{\mathrm{a}}$ & $0.44^{\mathrm{b}}$ & $0.32^{\mathrm{ab}}$ & 0.053 & 0.058 \\
\hline C14:0 & 1.65 & 1.94 & 1.85 & 0.162 & 0.245 \\
\hline $\mathrm{C} 16: 0$ & $24.3^{\mathrm{a}}$ & $28.3^{\mathrm{b}}$ & $34.5^{\mathrm{c}}$ & 1.55 & $<0.001$ \\
\hline $\mathrm{C} 16: 1 n-7$ & 0.17 & 0.15 & 0.15 & 0.032 & 0.853 \\
\hline Phytanic acid & $4.49^{\mathrm{c}}$ & $3.47^{\mathrm{b}}$ & $1.74^{\mathrm{a}}$ & 0.222 & $<0.001$ \\
\hline $\mathrm{C} 18: 0$ & 71.1 & 75.7 & 77.1 & 4.48 & 0.412 \\
\hline$\Sigma \mathrm{C} 18: 1 \mathrm{cis}$ & $3.85^{\mathrm{a}}$ & $3.96^{\mathrm{a}}$ & $6.50^{\mathrm{b}}$ & 0.315 & $<0.001$ \\
\hline$\Sigma \mathrm{C} 18: 1$ trans & $8.97^{\mathrm{a}}$ & $12.6^{\mathrm{b}}$ & $13.5^{\mathrm{b}}$ & 0.732 & $<0.001$ \\
\hline$\Sigma$ CLA & $0.22^{\mathrm{a}}$ & $0.26^{\mathrm{a}}$ & $0.79^{b}$ & 0.027 & $<0.001$ \\
\hline$\Sigma \mathrm{C} 18: 2 \mathrm{NC}^{5}$ & $1.16^{\mathrm{a}}$ & $1.90^{\mathrm{b}}$ & $2.66^{\mathrm{c}}$ & 0.269 & $<0.001$ \\
\hline C18:2n-6 & $1.55^{\mathrm{a}}$ & $2.54^{\mathrm{b}}$ & $7.22^{\mathrm{c}}$ & 0.290 & $<0.001$ \\
\hline $\mathrm{C} 18: 3 n-3$ & $2.43^{\mathrm{a}}$ & $4.44^{b}$ & $13.5^{\mathrm{c}}$ & 0.527 & $<0.001$ \\
\hline C20:0 & $2.73^{\mathrm{b}}$ & $1.86^{\mathrm{a}}$ & $2.50^{\mathrm{b}}$ & 0.170 & 0.003 \\
\hline BOC fatty acids & $20.0^{\mathrm{c}}$ & $16.2^{\mathrm{b}}$ & $13.1^{\mathrm{a}}$ & 0.96 & $<0.001$ \\
\hline Total & $148^{\mathrm{a}}$ & $160^{\mathrm{a}}$ & $187^{\mathrm{b}}$ & 8.1 & 0.004 \\
\hline
\end{tabular}

${ }^{\mathrm{a}-\mathrm{c}}$ Means within row not bearing a common letter differ $(P<0.05)$.

${ }^{1} \mathrm{CO}=$ cocksfoot silage; $\mathrm{PR}=$ perennial ryegrass silage $\mathrm{RC}=$ red clover silage.

${ }^{2} \mathrm{BOC}=$ branched and odd chain.

${ }^{3} \mathrm{OMAD}=\mathrm{OM}$ apparently digested: $\%=(\mathrm{OM}$ intake $-\mathrm{OM}$ flow $) / \mathrm{OM}$ intake $\times 100$.

${ }^{4}$ OMTD $=$ OM truly digested: $\%=[\mathrm{OM}$ intake $-(\mathrm{OM}$ flow - microbial OM flow)] $/$ OM intake $\times 100$.

${ }^{5} \mathrm{NC}=$ nonconjugated.

and PR there was little change in $\mathrm{pH}$ across the day. Similar to the $0800 \mathrm{~h}$ feeding, the $1600 \mathrm{~h}$ feeding resulted in a drop in $\mathrm{pH}$ for $\mathrm{RC}$ but there was little change for either $\mathrm{CO}$ or PR. The temporal pattern of total VFA concentration in the rumen followed the opposite pattern of $\mathrm{pH}$, as expected (Fig. 1b). Total VFA, propionate, and $n$-butyrate were greatest for PR with $\mathrm{CO}$ and $\mathrm{RC}$ not different from each other, with the exception of $n$-butyrate, where $\mathrm{CO}$ was lower than RC. $n$-Valerate and the ratio of propionate:(acetate $+i$-butyrate $+n$-butyrate) followed the pattern $\mathrm{RC}>\mathrm{PR}=\mathrm{CO}$. Acetate, $i$-butyrate, and $i$-valerate were lowest with $\mathrm{RC}$ and, with 
Table 4. Percentages of $\mathrm{C} 18: 1$ isomers in the duodenal digesta of steers fed the 3 silage diets

\begin{tabular}{lccccc}
\hline \hline Item & $\mathrm{CO}^{1}$ & $\mathrm{PR}^{1}$ & $\mathrm{RC}^{1}$ & $\mathrm{SED}$ & $P$-value \\
\hline $\mathrm{C} 18: 1$ cis & & & & & \\
9 & $67.5^{\mathrm{a}}$ & $77.9^{\mathrm{b}}$ & $74.7^{\mathrm{b}}$ & 1.78 & $<0.001$ \\
11 & $10.5^{\mathrm{a}}$ & $15.3^{\mathrm{c}}$ & $12.1^{\mathrm{b}}$ & 0.65 & $<0.001$ \\
12 & $18.3^{\mathrm{c}}$ & $1.4^{\mathrm{a}}$ & $5.8^{\mathrm{b}}$ & 1.91 & $<0.001$ \\
13 & 0.40 & 1.24 & 1.22 & 0.50 & 0.218 \\
15 & $3.37^{\mathrm{a}}$ & $4.13^{\mathrm{a}}$ & $6.14^{\mathrm{b}}$ & 0.47 & $<0.001$ \\
$\mathrm{C} 18: 1$ trans & & & & & \\
4 & 0.25 & 0.27 & 0.39 & 0.010 & 0.325 \\
5 & 0.29 & 0.28 & 0.26 & 0.14 & 0.982 \\
6,7, or 8 & 3.80 & 3.56 & 3.70 & 0.31 & 0.733 \\
9 & 2.38 & 2.35 & 2.39 & 0.14 & 0.956 \\
10 & $3.06^{\mathrm{a}}$ & $3.21^{\mathrm{a}}$ & $4.07^{\mathrm{b}}$ & 0.22 & 0.003 \\
11 & $67.5^{\mathrm{b}}$ & $66.9^{\mathrm{b}}$ & $40.1^{\mathrm{a}}$ & 1.82 & $<0.001$ \\
12 & $3.82^{\mathrm{a}}$ & $3.96^{\mathrm{a}}$ & $7.94^{\mathrm{b}}$ & 0.36 & $<0.001$ \\
13 or 14 & $5.62^{\mathrm{a}}$ & $5.81^{\mathrm{a}}$ & $11.79^{\mathrm{b}}$ & 0.378 & $<0.001$ \\
15 & $4.93^{\mathrm{a}}$ & $5.38^{\mathrm{a}}$ & $12.12^{\mathrm{b}}$ & 0.505 & $<0.001$ \\
16 & $8.34^{\mathrm{a}}$ & $8.31^{\mathrm{a}}$ & $17.28^{\mathrm{b}}$ & 0.843 & $<0.001$ \\
\hline
\end{tabular}

${ }^{\mathrm{a}-\mathrm{c}}$ Means within row not bearing a common letter $\operatorname{differ}(P<0.05)$.

${ }^{1} \mathrm{CO}=$ cocksfoot silage; $\mathrm{PR}=$ perennial ryegrass silage; $\mathrm{RC}=$ red clover silage.

the exception of $i$-valerate, where $\mathrm{CO}$ was greater than PR, there was no difference between the grasses. Temporal ruminal ammonia-N is shown in Fig. 1c, with ammonia-N increasing following the $0800 \mathrm{~h}$ feeding to reach a peak at $1000 \mathrm{~h}$ of 207, 163, and $143 \mathrm{mg} \mathrm{N} / \mathrm{L}$ for RC, PR, and CO, respectively. Levels then declined to prefeeding levels by $1600 \mathrm{~h}$ before increasing following feeding. Mean ruminal ammonia-N across the day is reported in Table 5, with a greater concentration in RC-fed animals compared to either $\mathrm{PR}$ and $\mathrm{CO}$. The temporal difference between RC and both $\mathrm{CO}$ and PR was significant between 0900 and $1100 \mathrm{~h}$, with all other sampling times having comparable values.

\section{Intake and Duodenal Flow of $N$ and $A A$}

Intake and duodenal flow of $\mathrm{N}$ and $\mathrm{AA}$ are reported in Table 6. Total $\mathrm{N}$ intake and all individual and total AA intakes with the exception of methionine followed the pattern $\mathrm{RC}>\mathrm{PR}>\mathrm{CO}$. For intake of methionine, $\mathrm{PR}$ was greater than the other 2 silage diets, which were comparable. For duodenal flow of total $\mathrm{N}$ and individual and total AA with the exception of glycine and tyrosine, the same pattern as for intake existed with $\mathrm{RC}>\mathrm{PR}>\mathrm{CO}$. Glycine and tyrosine flow was not different between PR and $\mathrm{CO}$, with $\mathrm{RC}$ greater than both. Total microbial AA flow was lowest for $\mathrm{CO}$, with no difference between $\mathrm{RC}$ and PR. Total nonmicrobial AA flow was greater for RC than either $\mathrm{CO}$ or PR, with no difference between the grasses. Total N and nonmicrobial N (NMN; dietary N + ammonia- $\mathrm{N}+$ endogenous- $\mathrm{N}$ ) flow followed the same pattern as $\mathrm{N}$ intake. Microbial $\mathrm{N}$ flow and efficiency of microbial protein synthesis (EMPS), measured as either microbial $\mathrm{N}$ per kilogram of OM apparently digested or OM truly
Table 5. Rumen parameters in steers fed the 3 silage diets

\begin{tabular}{|c|c|c|c|c|c|}
\hline Item & $\mathrm{CO}^{1}$ & $\mathrm{PR}^{1}$ & $\mathrm{RC}^{1}$ & SED & $P$-value \\
\hline \multicolumn{6}{|l|}{ Biohydrogenation, $\%$} \\
\hline C18:2n-6 & $90.6^{\mathrm{c}}$ & $87.9^{\mathrm{b}}$ & $77.9^{\mathrm{a}}$ & 0.72 & $<0.001$ \\
\hline $\mathrm{C} 18: 3 n-3$ & $94.4^{\mathrm{c}}$ & $92.1^{\mathrm{b}}$ & $77.6^{\mathrm{a}}$ & 0.43 & $<0.001$ \\
\hline $\mathrm{pH}^{2}$ & $6.80^{\mathrm{c}}$ & $6.67^{\mathrm{a}}$ & $6.74^{\mathrm{b}}$ & 0.020 & $<0.001$ \\
\hline Total VFA, $\mathrm{mmol} / \mathrm{L}^{2}$ & $80.5^{\mathrm{a}}$ & $87.1^{\mathrm{b}}$ & $76.4^{\mathrm{a}}$ & 2.40 & 0.003 \\
\hline Ratio $[\operatorname{Pr} /(\mathrm{A}+\mathrm{Bu})]^{2,3}$ & $0.23^{\mathrm{a}}$ & $0.24^{\mathrm{b}}$ & $0.25^{\mathrm{c}}$ & 0.004 & $<0.001$ \\
\hline Acetate, $\mathrm{mmol} / \mathrm{L}^{2}$ & $56.8^{\mathrm{b}}$ & $59.4^{\mathrm{b}}$ & $51.3^{\mathrm{a}}$ & 1.83 & 0.003 \\
\hline Propionate, $\mathrm{mmol} / \mathrm{L}^{2}$ & $14.4^{\mathrm{a}}$ & $16.4^{\mathrm{b}}$ & $14.8^{\mathrm{a}}$ & 0.46 & 0.003 \\
\hline$i$-Butyrate, $\mathrm{mmol} / \mathrm{L}^{2}$ & $1.18^{\mathrm{b}}$ & $1.17^{b}$ & $1.05^{\mathrm{a}}$ & 0.05 & 0.051 \\
\hline$n$-Butyrate, $\mathrm{mmol} / \mathrm{L}^{2}$ & $6.01^{\mathrm{a}}$ & $8.13^{\mathrm{c}}$ & $7.35^{\mathrm{b}}$ & 0.192 & $<0.001$ \\
\hline$i$-Valerate, $\mathrm{mmol} / \mathrm{L}^{2}$ & $1.27^{\mathrm{c}}$ & $1.10^{\mathrm{b}}$ & $0.86^{\mathrm{a}}$ & 0.033 & $<0.001$ \\
\hline$n$-Valerate, $\mathrm{mmol} / \mathrm{L}^{2}$ & $0.75^{\mathrm{a}}$ & $0.89^{\mathrm{b}}$ & $1.06^{\mathrm{c}}$ & 0.036 & $<0.001$ \\
\hline Ammonia-N, mg N/L ${ }^{2}$ & $98^{\mathrm{a}}$ & $103^{\mathrm{a}}$ & $124^{\mathrm{c}}$ & 4.01 & 0.004 \\
\hline
\end{tabular}

digested, was not different for $\mathrm{RC}$ and $\mathrm{PR}$, which were both greater than $\mathrm{CO}$. The microbial $\mathrm{N}$ flow as a percentage of $\mathrm{N}$ intake was greater for PR followed by $\mathrm{CO}$ and lowest for RC. No difference was found when the NMN flow was reported as a percentage of $\mathrm{N}$ intake.

\section{DISCUSSION}

\section{Silage Composition}

When ensiling big bales, the aim is to achieve a DM between 35 and $45 \%$; often, extended wilts of up to $48 \mathrm{~h}$ are used. In the current trial, the DM of CO achieved the target but the extended wilt for PR and RC produced greater DM than expected at 56 and $45 \%$, respectively. High-DM silage can result in poor conservation due to poor compaction and reduced ability to remove oxygen from the clamp/bale. The resultant dry crop increased the need for a bacterial inoculant, which resulted in well-preserved silage despite the high DM content. The high DM resulted in relatively high $\mathrm{pH}$ in all silages with low fermentation acid concentrations. The relatively high level of WSC in PR was related to the high-sugar grass selected (cv. AberStar) and the use of bacterial inoculant, which also resulted in relatively high levels of WSC in RC (Harrison et al., 1994; Merry et al., 2006). The chemical composition of CO was typical of that previously reported with low WSC and high NDF (Aufrère et al., 2003; Kammes and Allen, 2012). Polyphenol oxidase activity in all silages was low due to rapid deactivation of PPO by quinone binding formed through the PPO-catalyzed conversion of diphenol substrate as a negative feedback of PPO activity (Lee et al., 2013). Lee et al. (2013) reported a rapid decline in PPO activity in macerated red clover within $1 \mathrm{~h}$, with the rate relating to the extent of damage of the crop. Deactivation would continue to occur whilst 

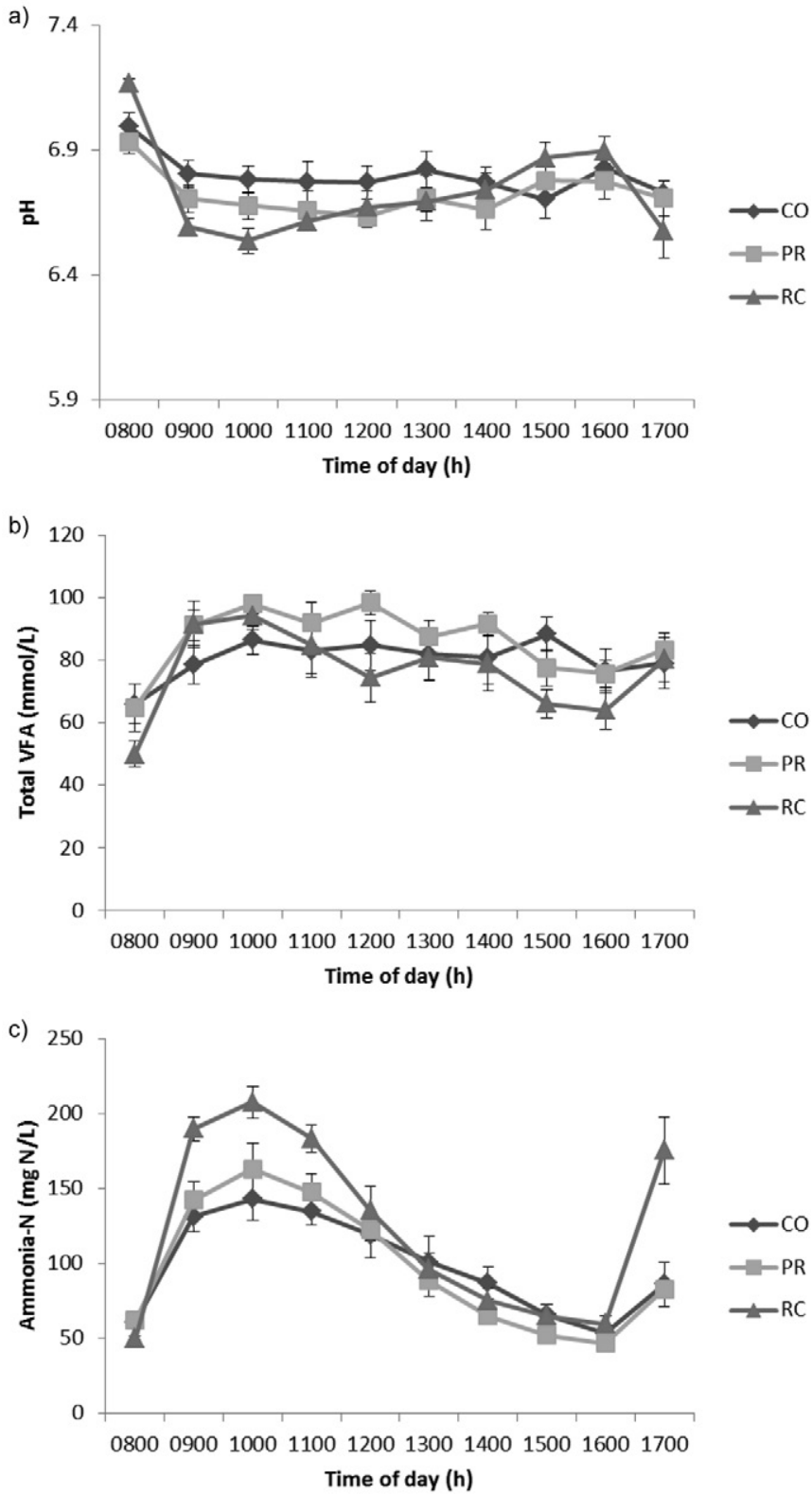

Figure 1. Hourly ruminal parameters for (a) $\mathrm{pH}$, (b) total VFA, and (c) ammonia-N of fistulated steers fed the experimental silages cocksfoot silage $(\mathrm{CO})$, perennial ryegrass silage $(\mathrm{PR})$, or red clover silage $(\mathrm{RC})$. Error bars $=\mathrm{SEM}$

there is sufficient oxygen and diphenol substrate, and this may explain the comparable levels of PPO in PR and RC as there is a greater proportion of substrate and enzyme to produce quinones in $\mathrm{RC}$ than $\mathrm{PR}$, resulting in greater $\mathrm{PPO}$ inactivation. The $\mathrm{CO}$ had the greatest level of PPO activity in silage, which may relate to lower levels of substrate in CO compared to RC (Parveen et al., 2010; Marita et al., 2010). The greater level of PPO activity in the fresh crop (not measured) resulted in greater levels of PBP in RC compared to PR and CO (Winters and Minchin, 2001). The difference between CO and PR in terms of PBP was small despite the greater reported level of PPO activity in CO compared to PR (Lee et al., 2006b; Marita et al., 2010). Greater levels of diphenol substrate have been reported in
Table 6. Intake and duodenal flow of $\mathrm{N}$ and AA in steers fed the 3 silage diets

\begin{tabular}{|c|c|c|c|c|c|}
\hline Item & $\mathrm{CO}^{1}$ & $\mathrm{PR}^{1}$ & $\mathrm{RC}^{1}$ & SED & $P$-value \\
\hline \multicolumn{6}{|l|}{ Intake, g/d } \\
\hline Total N & $112^{\mathrm{a}}$ & $132^{\mathrm{b}}$ & $198^{\mathrm{c}}$ & 5.04 & $<0.001$ \\
\hline Aspartic acid & $27.9^{\mathrm{a}}$ & $50.6^{\mathrm{b}}$ & $105.2^{\mathrm{c}}$ & 2.90 & $<0.001$ \\
\hline Threonine & $16.1^{\mathrm{a}}$ & $25.9^{\mathrm{b}}$ & $39.4^{\mathrm{c}}$ & 1.04 & $<0.001$ \\
\hline Serine & $10.7^{\mathrm{a}}$ & $22.7^{\mathrm{b}}$ & $38.5^{\mathrm{c}}$ & 1.14 & $<0.001$ \\
\hline Glutamic acid & $24.6^{\mathrm{a}}$ & $38.1^{\mathrm{b}}$ & $75.1^{\mathrm{c}}$ & 2.05 & $<0.001$ \\
\hline Proline & $24.3^{\mathrm{a}}$ & $34.0^{\mathrm{b}}$ & $58.2^{\mathrm{c}}$ & 1.32 & $<0.001$ \\
\hline Glycine & $19.4^{\mathrm{a}}$ & $26.8^{\mathrm{b}}$ & $38.4^{\mathrm{c}}$ & 0.99 & $<0.001$ \\
\hline Alanine & $30.5^{\mathrm{a}}$ & $36.8^{\mathrm{b}}$ & $47.6^{\mathrm{c}}$ & 1.18 & $<0.001$ \\
\hline Valine & $24.1^{\mathrm{a}}$ & $32.4^{\mathrm{b}}$ & $50.5^{\mathrm{c}}$ & 1.25 & $<0.001$ \\
\hline Methionine & $3.5^{\mathrm{a}}$ & $8.8^{\mathrm{b}}$ & $4.1^{\mathrm{a}}$ & 0.56 & $<0.001$ \\
\hline Isoleucine & $19.6^{\mathrm{a}}$ & $26.3^{b}$ & $42.6^{\mathrm{c}}$ & 1.04 & $<0.001$ \\
\hline Leucine & $33.1^{\mathrm{a}}$ & $45.3^{\mathrm{b}}$ & $70.2^{\mathrm{c}}$ & 1.80 & $<0.001$ \\
\hline Tyrosine & $7.28^{\mathrm{a}}$ & $15.5^{\mathrm{b}}$ & $27.0^{\mathrm{c}}$ & 0.84 & $<0.001$ \\
\hline Phenylalanine & $20.8^{\mathrm{a}}$ & $30.0^{\mathrm{b}}$ & $45.5^{\mathrm{a}}$ & 1.30 & $<0.001$ \\
\hline Histidine & $7.08^{\mathrm{a}}$ & $11.0^{\mathrm{b}}$ & $18.6^{\mathrm{c}}$ & 0.52 & $<0.001$ \\
\hline Lysine & $16.6^{\mathrm{a}}$ & $30.3^{\mathrm{b}}$ & $50.2^{\mathrm{c}}$ & 1.56 & $<0.001$ \\
\hline Arginine & $10.1^{\mathrm{a}}$ & $24.3^{\mathrm{b}}$ & $40.9^{c}$ & 1.41 & $<0.001$ \\
\hline Total AA & $296^{\mathrm{a}}$ & $459^{\mathrm{b}}$ & $753^{c}$ & 19.7 & $<0.001$ \\
\hline \multicolumn{6}{|l|}{ Duodenal flow, g/d } \\
\hline Total N & $121^{\mathrm{a}}$ & $161^{\mathrm{b}}$ & $204^{c}$ & 10.2 & $<0.001$ \\
\hline Microbial N & $54.9^{\mathrm{a}}$ & $77.2^{\mathrm{b}}$ & $76.3^{\mathrm{b}}$ & 5.09 & 0.003 \\
\hline Nonmicrobial $\mathrm{N}^{2}$ & $66.1^{\mathrm{a}}$ & $83.8^{\mathrm{b}}$ & $128.2^{\mathrm{c}}$ & 7.89 & 0.002 \\
\hline Aspartic acid & $46.6^{\mathrm{a}}$ & $65.5^{\mathrm{b}}$ & $91.1^{\mathrm{c}}$ & 6.52 & $<0.001$ \\
\hline Threonine & $22.8^{\mathrm{a}}$ & $31.2^{\mathrm{b}}$ & $43.1^{\mathrm{c}}$ & 6.86 & $<0.001$ \\
\hline Serine & $18.4^{\mathrm{a}}$ & $25.1^{\mathrm{b}}$ & $37.9^{\mathrm{c}}$ & 2.38 & $<0.001$ \\
\hline Glutamic acid & $47.8^{\mathrm{a}}$ & $67.4^{\mathrm{b}}$ & $95.6^{\mathrm{c}}$ & 6.68 & $<0.001$ \\
\hline Proline & $19.9^{\mathrm{a}}$ & $26.7^{\mathrm{b}}$ & $40.8^{\mathrm{c}}$ & 2.80 & $<0.001$ \\
\hline Glycine & $28.5^{\mathrm{a}}$ & $37.7^{\mathrm{a}}$ & $57.4^{\mathrm{b}}$ & 4.95 & $<0.001$ \\
\hline Alanine & $27.1^{\mathrm{a}}$ & $38.2^{\mathrm{b}}$ & $50.1^{\mathrm{c}}$ & 3.62 & $<0.001$ \\
\hline Valine & $24.1^{\mathrm{a}}$ & $33.8^{\mathrm{b}}$ & $50.4^{\mathrm{c}}$ & 3.37 & $<0.001$ \\
\hline Methionine & $9.4^{\mathrm{a}}$ & $13.8^{\mathrm{b}}$ & $16.6^{\mathrm{c}}$ & 1.28 & 0.002 \\
\hline Isoleucine & $23.2^{\mathrm{a}}$ & $32.7^{\mathrm{b}}$ & $47.3^{\mathrm{c}}$ & 3.20 & $<0.001$ \\
\hline Leucine & $33.6^{\mathrm{a}}$ & $47.2^{\mathrm{b}}$ & $72.9^{\mathrm{c}}$ & 4.58 & $<0.001$ \\
\hline Tyrosine & $18.7^{\mathrm{a}}$ & $25.4^{\mathrm{a}}$ & $36.8^{\mathrm{b}}$ & 3.16 & $<0.001$ \\
\hline Phenylalanine & $25.2^{\mathrm{a}}$ & $35.5^{\mathrm{b}}$ & $52.2^{\mathrm{c}}$ & 3.81 & $<0.001$ \\
\hline Histidine & $8.9^{\mathrm{a}}$ & $11.9^{\mathrm{b}}$ & $19.9^{\mathrm{c}}$ & 1.27 & $<0.001$ \\
\hline Lysine & $30.2^{\mathrm{a}}$ & $42.2^{\mathrm{b}}$ & $59.9^{\mathrm{c}}$ & 4.20 & $<0.001$ \\
\hline Arginine & $20.0^{\mathrm{a}}$ & $28.0^{\mathrm{b}}$ & $44.6^{\mathrm{c}}$ & 2.97 & $<0.001$ \\
\hline Total AA & $403^{\mathrm{a}}$ & $567^{\mathrm{b}}$ & $818^{c}$ & 58.4 & $<0.001$ \\
\hline Total microbial $\mathrm{AA}^{3}$ & $239^{a}$ & $337^{\mathrm{b}}$ & $333^{\mathrm{b}}$ & 25.4 & 0.004 \\
\hline Total nonmicrobial $\mathrm{AA}^{4}$ & $164^{\mathrm{a}}$ & $230^{\mathrm{a}}$ & $485^{\mathrm{b}}$ & 55.1 & 0.001 \\
\hline EMPS $^{5}$ & $27.0^{\mathrm{a}}$ & $35.0^{\mathrm{b}}$ & $36.6^{\mathrm{b}}$ & 3.32 & 0.041 \\
\hline EMPS $^{6}$ & $18.3^{\mathrm{a}}$ & $21.3^{\mathrm{b}}$ & $22.0^{\mathrm{b}}$ & 1.17 & 0.026 \\
\hline Microbial N/NI, ${ }^{7} \%$ & $48.9^{\mathrm{b}}$ & $58.1^{\mathrm{c}}$ & $38.5^{\mathrm{a}}$ & 3.27 & 0.001 \\
\hline $\mathrm{NMN} / \mathrm{NI},{ }^{8} \%$ & 59.0 & 63.3 & 65.2 & 5.26 & 0.513 \\
\hline
\end{tabular}

${ }^{\mathrm{a}-\mathrm{c}}$ Means within row not bearing a common letter differ $(P<0.05)$.

${ }^{1} \mathrm{CO}=$ cocksfoot silage; $\mathrm{PR}=$ perennial ryegrass silage; $\mathrm{RC}=$ red clover silage.

${ }^{2}$ Combination of dietary and ammonia-N.

${ }^{3}$ Total microbial AA $=$ microbial $\mathrm{N} \times 6.25 \times 0.7$ (Hvelplund, 1986).

${ }^{4}$ Total nonmicrobial $\mathrm{AA}=$ total $\mathrm{AA}-$ total microbial AA.

${ }^{5} \mathrm{EMPS}=$ efficiency of microbial protein synthesis: $g$ microbial $\mathrm{N} / \mathrm{kg} \mathrm{OM}$ apparently digested in the rumen.

${ }^{6} \mathrm{EMPS}: \mathrm{g}$ microbial $\mathrm{N} / \mathrm{kg}$ OM truly digested in the rumen.

${ }^{7}$ Microbial $\mathrm{N}$ at the duodenum as a percentage of $\mathrm{N}$ intake (NI).

${ }^{8}$ Nonmicrobial N (NMN; dietary + ammonia + endogenous) at the duodenum as a percentage of $\mathrm{N}$ intake. 
PR compared to CO (Parveen et al., 2010), and even in the absence of or at a low level of PPO, PBP has been reported to be formed through autoxidation or peroxidase-driven oxidation of diphenols, especially during an extended wilt (Lee et al., 2013). Also, despite the fact that PBP is often used to determine the level of PPO oxidation and subsequent protein complexing, the assay will only determine the level of bound soluble protein and is unable to measure bound-nonsoluble protein, which will increase as complexing increases and protein loses solubility. The PBP method therefore should only be used as an indicator of oxidation and not total protein complexing, which would be related to protein protection. However, the similar level of PBP between $\mathrm{CO}$ and $\mathrm{PR}$ could help explain the greater proportion of ammonia-N in total silage $\mathrm{N}$ for $\mathrm{CO}$ than PR or RC (14, 8 , and $7 \%$, respectively). Polyphenol oxidase complexing of protein has been reported to reduce proteolysis in silo (Albrecht and Muck, 1991) and so reduce loss of protein as ammonia. The greater levels of ammonia-N in CO may be related to a reduced protein complexing through PPO or a combination of an extended wilt and the greater $\mathrm{pH}$ of the silage resulting in greater protease activity increasing proteolysis. The latter explanation would explain the greater ammonia-N (\% total $\mathrm{N}$ ) for silages in the current study than typical reported values for red clover (3\%; Vanhatalo et al., 2009), perennial ryegrass (6\%), and cocksfoot $(6 \%$; Aufrère et al., 2003). The use of a formic acid silage inoculant by Vanhatalo et al. (2009) and Aufrère et al. (2003) as opposed to live culture in the current study may also have influenced ammonia-N.

The concentrations of fatty acids in the 3 silages are lower than typical reported values for ryegrass, red clover, and cocksfoot, although the proportions of individual fatty acids are comparable with the literature (Lee et al., 2006a; Dierking, 2008; Halmemies-Beauchet-Filleau et al., 2013). This may relate to the greater maturity (second cut) of the crops in the current study as shown by their fiber composition, as maturity is related to lower fatty acid content of herbage (Dewhurst et al., 2001). Greater levels of phytanic acid in $\mathrm{CO}$ is an indication of chlorophyll degradation (Patton and Benson, 1966) and, as Dierking (2008) reported typically lower levels of total chlorophyll in cocksfoot compared with perennial ryegrass, it would suggest greater enzymatic activity in $\mathrm{CO}$ than PR and RC. This agrees with the greater ammonia-N levels as mentioned above and could indicate extended plant enzyme activity in contrast to the hypothesis of rapid $\mathrm{PPO}$-induced deactivation of plant enzyme activity. However, the greater levels of BOC fatty acids associated with microbial membranes in CO may suggest that the elevated enzymatic degradation of protein and chlorophyll could be driven by microbial enzymes less affected by PPO complexing. Other differences between the grasses such as potentially greater enzyme content within $\mathrm{CO}$, however, cannot be ruled out. Amino acid concentrations and compositions are similar to those reported in the literature based on the level of CP for grasses and legumes (Wilson and Tilley, 1965; Lee et al., 2002; HalmemiesBeauchet-Filleau et al., 2014).

\section{Dry Matter Intake, Ruminal pH, and VFA}

When offered for ad libitum intake, legume silage typically shows greater levels of intake than grass silages in comparison studies due to greater digestibility of the former (Lee et al., 2006a; Kammes and Allen, 2012). In the current study, however, all silages were limited to 16 $\mathrm{g} \mathrm{DM} / \mathrm{kg} \mathrm{BW}$ daily, which should equate to a range of intakes between 6.27 to $7.01 \mathrm{~kg} \mathrm{DM} / \mathrm{d}$ based on the mean and variance of animal BW. As only PR falls within this range, it would appear that the DM content of RC was underestimated during feeding, resulting in more $\mathrm{RC}$ being offered than the $16 \mathrm{~g} \mathrm{DM} / \mathrm{kg} \mathrm{BW}$ daily allowance, whereas $\mathrm{CO}$ intake was affected due to the low palatability of the high-fiber silage, as animals did not consume all silage offered. Palatability/maturity of silage has been reported to significantly affect intake in grass silages to a greater extent than legume silages (Harrison et al., 1994; Kuoppala et al., 2009). Ruminal pH mean values were typically greater than those previously reported for animals offered a sole forage diet (Lee et al., 2002; Merry et al., 2006) and may relate to the high DM and fiber content of the experimental silages. There was an interaction effect (treatment $\times$ diet) for ruminal $\mathrm{pH}$, with the grasses showing little change across the measurement period, whereas $\mathrm{RC}$ showed significant declines in $\mathrm{pH}$ associated with feeding. This typically reflects an ad libitum consumption pattern for the grasses where animals more typically grazed through the day (Lee et al., 2002), whereas the $\mathrm{RC}$ animals consumed the majority of the feed in 1 session after feeding, resulting in a drop in ruminal $\mathrm{pH}$ and a subsequent rise until the next feeding (Lee et al., 2006a). Volatile fatty acid concentrations in the rumen are similar to those previously reported from steers consuming grass or red clover silage (Merry et al., 2006). Although statistical differences were found between individual VFA, numerical differences and molar proportions (not reported) were small. The greater propionate levels with PR may reflect the greater supply of readily available energy as previously reported (Lee et al., 2002), although the molar proportion differences were small and unlikely to be biologically significant. The greater concentrations of the branched chain $i$-butyrate and $i$-valerate in the rumen help explain the greater flow of BOC fatty acids at the duodenum, as these VFA are the precursors of BOC fatty acid biosynthesis. They are also indicative of dietary AA degradation in the rumen as a consequence of high-fiber and low-available-energy diets. 


\section{Fatty Acid Metabolism across the Rumen}

Duodenal flow of fatty acids on all forage diets exceeded intake by 58,33 , and $30 \%$ for $\mathrm{CO}, \mathrm{PR}$, and $\mathrm{RC}$, respectively. This is consistent with net gain due to microbial fatty acid synthesis de novo in cattle fed diets containing low amounts of lipid, such as forage-only diets (Lee et al., 2006a; Halmemies-Beauchet-Filleau et al., 2013). The response was greater with $\mathrm{CO}$ as exemplified by a greater proportional increase in fatty acids associated with microbial lipids, namely $\mathrm{C} 16: 0$ and BOC fatty acids (Vlaeminck et al., 2006). The $\mathrm{CO}$ also resulted in a greater flow of phytanic acid than either PR or RC, which would indicate a greater microbial degradation of chlorophyll in the rumen. The RC had lower levels of this chlorophyll metabolite than either grass, as previously reported (Lee et al., 2006a; Halmemies-Beauchet-Filleau et al., 2013). Perennial ryegrass and red clover silage typically have similar amounts of chlorophyll (Lee et al., 2006a), suggesting a protective attribute of red clover yet to be elucidated. Such an attribute may relate to the protective nature of RC in terms of biohydrogenation discussed below.

The changes in the $\mathrm{C} 18$ fatty acid pool between intake of high levels of PUFA and low levels of SFA to duodenal flows with low levels of PUFA, high levels of SFA, and a range of conjugated dienes and monounsaturated trans and cis fatty acid intermediates is a result of ruminal microbial biohydrogenation. As hypothesized in the current study and as exemplified in numerous studies recently reviewed by Buccioni et al. (2012), the high-PPO RC treatment resulted in a significant reduction in biohydrogenation with a greater protection of PUFA across the rumen. In contrast, the high-PPO grass $\mathrm{CO}$ did not result in a greater protection of PUFA and in fact resulted in a greater loss of PUFA across the rumen. The mechanism for RC protection of PUFA across the rumen is yet to be fully elucidated but may be mediated via several interrelated mechanisms. These include possible formation of protein complexes as a consequence of PPO activity, alterations in digestion kinetics, forage particle size distribution in the rumen, and ruminal microbial ecology (Halmemies-Beauchet-Filleau et al., 2013). Our data suggest that PPO has little effect on biohydrogenation in vivo as the high grass PPO treatment, $\mathrm{CO}$, failed to show any protection of PUFA compared to the low grass PPO treatment. Although other differences between grasses must be acknowledged, the results are not indicative of a PPO protective response in grass. There is little doubt that PPO in both red clover and grasses can deactivate lipase activity (Lee et al., 2006b; Van Ranst et al., 2011). However, for PPO to protect lipid in the ruminal environment, there appears to be a requirement for the lipid to be complexed within PBP, which would limit microbial lipase access to the PUFA-glycerol ester bond (Lee et al., 2010). In the current study, the level of PBP was comparable between $\mathrm{CO}$ and $\mathrm{PR}$, which may suggest a similar level of lipid PBP complexing. The ability to complex protein is driven by enzyme activity, protein AA composition, and diphenolic substrate (Lee et al., 2013). If all 3 are optimum, protein complexing will be severe, resulting in the protein losing solubility, which will not be measured by PBP; therefore, PBP may underestimate complexing in high-PPO crops such as red clover and cocksfoot. If so, the inability of protein complexing in $\mathrm{CO}$ to elicit the protective effect of red clover may be due to protein AA composition (lower nucleophilic binding sites) or substrate differences; this is further explored below. It may also suggest, as it has yet to be proven, that PPO-induced protein complexing does little to protect esterified PUFA in vivo and the greater flow of esterified lipid at the omasum reported by Halmemies-Beauchet-Filleau et al. (2013) when animals consumed red clover-based diets is related to either alterations in digestion kinetics, forage particle size distribution in the rumen, or changes in ruminal microbial ecology (Huws et al., 2010).

Proportions of C18:1 cis were different between the 2 grasses, whereas C18:1 trans proportions were similar, which suggests similar $\mathrm{C} 18$ biohydrogenation pathways for both grasses in the rumen. The differences observed in $\mathrm{C} 18: 1$ cis were driven by the large proportion of $\mathrm{C} 18: 1$ cis-12 in the duodenal flow of CO-fed animals. The CO was found to contain $8 \%$ of its C18:1 cis fatty acids as cis12 and cis-12 was absent in both PR and RC, which may help to at least partly explain the differences in duodenal proportions. The proportions of C18:1 isomers between the grasses and $\mathrm{RC}$, in contrast, were markedly different, particularly in relation to C18:1 trans. Similar patterns to those observed in the current study between C18:1 isomer proportions were reported in animals consuming grass or red clover silage (Lee et al., 2006a). They suggested that these differences in C18:1 biohydrogenation intermediates could be related to differences in ruminal microbial communities influencing biohydrogenation pathways. This was later confirmed by Huws et al. (2010), who demonstrated that significantly different ruminal microbial communities developed when steers were offered either grass or red clover silage. This may possibly explain the reduction in biohydrogenation when ruminants consume red clover. However, when red clover or grass silages are fed in combination with concentrate (60:40 forage:concentrate, DM basis) the difference in C18:1 biohydrogenation intermediates is minimal but the reduction in PUFA biohydrogenation on the red clover:concentrate diet is still observed (Halmemies-Beauchet-Filleau et al., 2013). This would suggest that the high starch concentrate would mask any forage effects that may drive microbial differences and that the reduction in biohydrogenation is not driven by the different microbial community. Further work is therefore required to determine the exact nature of the protection of PUFA across the rumen on a red clover diet. 


\section{Nitrogen and AA Metabolism across the Rumen}

Ammonia-N in the rumen was significantly greater on $\mathrm{RC}$ compared to the 2 grass diets relating to $\mathrm{N}$ intake. The EMPS for forage silage were greater than those previously reported with sole forage diets, averaging 32.9 in the current study compared with an average of 23.5 reported by Merry et al. (2006) when EMPS was calculated as proportion of OM apparently digested and 20.5 vs. 16.5 , respectively, when calculated as a proportion of OM truly digested in the rumen. The greater values in the current study may relate to an overestimation of duodenal flow. Although values for apparent and true OM digestibility across the rumen on all forage diets are scarce in the literature, a meta-analysis of typical North American and European ruminant diets performed by Huhtanen et al. (2010) predicted values of 42 and $74 \%$ for apparent and true ruminal OM digestibilities compared with 37 and $56 \%$, respectively, in the current study, evidencing a potential overestimation of duodenal flow. Vanhatalo et al. (2009) reported significantly greater EMPS with red clover than grass silage when offered with a dairy concentrate ration $(60: 40$ forage:concentrate) although numerically similar to the values reported in the current study where there were no differences between RC and PR.

Greater total $\mathrm{N}$ flows entering the duodenum with $\mathrm{RC}$ than with either PR or CO were in agreement with previous results comparing red clover with grass (Dewhurst et al., 2003; Merry et al., 2006; Vanhatalo et al., 2009) and in part can be attributed to the greater $\mathrm{N}$ content of the $\mathrm{RC}$. The greater total $\mathrm{N}$ flow with the $\mathrm{RC}$ diet was composed mainly of NMN (dietary, endogenous, and ammonia $\mathrm{N}$ ). Thus, the contribution of microbial $\mathrm{N}$ to the total $\mathrm{N}$ flow was lower $(P<0.05)$ with red clover $(37 \%)$ than with PR $(48 \%)$ and CO (45\%). These findings agree with previous red clover versus grass silage comparisons (Dewhurst et al., 2003; Merry et al., 2006; Vanhatalo et al., 2009). Greater NMN with RC is reported to result from a lower N degradability in the rumen (Dewhurst et al., 2003; Merry et al., 2006; Vanhatalo et al., 2009) and has been attributed to the PPO activity inherent in red clover protecting dietary protein (Lee et al., 2004; Merry et al., 2006; Halmemies-Beauchet-Filleau et al., 2014). However, in the current study, no difference was observed between treatments when the flow of NMN was reported as a percentage of $\mathrm{N}$ intake $(62.5 \%)$, which coincidentally is also greater than previously reported for forage silage diets (33.8\%; Merry et al., 2006), further indicating a likely overestimation of duodenal flow in the current study. This lack of difference between treatments may in part be related to the greater proportional increase in $\mathrm{N}$ flow compared to $\mathrm{N}$ intake on the grass silage diets (1.08 and 1.22 for $\mathrm{CO}$ and PR, respectively) compared to RC (1.03), possibly due to greater $\mathrm{N}$ recycling on the grass treatments (discussed below). Al- though true RUP cannot be calculated in the present study due to lack of data on duodenal flow of ammonia N, the calculated flow of AA within the NMN fraction indicates a greater flow of dietary protein on the RC treatment compared to either grass treatment, with no difference between the high-PPO CO and low-PPO PR. This is in contrast to the findings of Aufrère et al. (2003), who reported that RUP (\% of dietary N) was greater for cocksfoot (10.9 to $15 \%$ ) than perennial ryegrass (5.8 to $10.1 \%$ ). Lee et al. (2011) also reported a greater protection of dietary protein for cocksfoot over tall fescue (Festuca arundinacea) in vitro through lower levels of ammonia-N released in culture per unit of $\mathrm{N}$ intake. The current study, however, showed little evidence for any difference between PR and $\mathrm{CO}$ for dietary $\mathrm{N}$ protection as assessed by either the proportion of NMN:N intake or the duodenal flow of nonmicrobial AA. The results indicate that duodenal flow of dietary protein for both grass silages was comparable and so CO did not demonstrate a greater protection of dietary $\mathrm{N}$ through the rumen despite its greater PPO content. The cocksfoot PPO enzyme and the substrate are different than that contained in red clover (Parveen et al., 2010; Marita et al., 2010). This, combined with the different level and composition (AA) of protein between the 2 forages, may result in cocksfoot PPO being unable to complex protein in the same way as red clover PPO and therefore unable to elicit a protective effect in the rumen. It also must be acknowledged that the chemical compositions of the 2 grasses were different and as such may have influenced protein breakdown independent of PPO.

Duodenal $\mathrm{N}$ flows as proportions of $\mathrm{N}$ intake were high-1.03, 1.08, and 1.22 for $\mathrm{RC}, \mathrm{CO}$, and $\mathrm{PR}$, respectively - suggesting an overestimation of duodenal flow as already indicated. However, Hume et al. (1970) demonstrated that ruminants could show duodenal $\mathrm{N}$ flows between 1.71 and 2.57 times $\mathrm{N}$ intake as a consequence of $\mathrm{N}$ recycling, but these levels are only achievable on severely N-deficient diets (5 to $10 \mathrm{~g} \mathrm{~N} / \mathrm{kg} \mathrm{DM}$ ). Values of duodenal $\mathrm{N}$ flow as a proportion of $\mathrm{N}$ intake reported for beef steers fed grass and red clover silage diets ranged from 0.73 to 1.03 (Merry et al., 2006), although total $\mathrm{N}$ content of their silages were greater (22.1 to $24.6 \mathrm{~g} / \mathrm{kg} \mathrm{DM}$ for grass and $32.9 \mathrm{~g} / \mathrm{kg}$ DM for red clover) than in our study.

Patterns of AA flow at the duodenum are similar to those previously reported when consuming grass and red clover silage (Lee et al., 2002; Vanhatalo et al., 2009). These studies with fresh forage highlight the low supply of histidine and methionine to the duodenum. Vanhatalo et al. (1999) showed the first 2 limiting AA for dairy cows on grass silage diets were histidine followed by methionine. These 2 particular AA are low in plant protein and must be considered when formulating rations for high-producing animals based on high forage rations. 


\section{Conclusion}

As previously reported, biohydrogenation of PUFA was lower and the flow of NMN (dietary N) was greater when animals consumed red clover as opposed to grass silage. Grass silage made from species with greater levels of PPO did not result in any protection of PUFA nor did it show greater flow of dietary protein (AA) to the duodenum compared with low-PPO grass silage.

\section{LITERATURE CITED}

Adler, E., and R. Magnusson. 1959. Treated methylcatechol with equimolar concentrated sodium periodate produces quinone products. Acta Chem. Scand. 13:505-519.

Albrecht, K. A., and G. A. Broderick. 1992. Ruminal in vitro degradation of protein from different legume species. In: Research summaries. U.S. Dairy Forage Research Center, Madison, WI. p. 92-94.

Albrecht, K. A., and R. E. Muck. 1991. Proteolysis in ensiled forage legumes that vary in tannin concentration. Crop Sci. 31:464-469.

Aufrère, J., D. Graviou, and C. Demarquilly. 2003. Ruminal degradation of protein of cocksfoot and perennial ryegrass as affected by various stages of growth and conservation methods. Anim. Res. 52:245-261.

Broderick, G. A., R. P. Walgenbach, and S. Maignan. 2001. Production of lactating dairy cows fed alfalfa or red clover silage at equal dry matter or crude protein contents in the diet. J. Dairy Sci. 84:1728-1737.

Buccioni, A., M. Decandia, S. Minieri, G. Molle, and A. Cabiddu. 2012. Lipid metabolism in the rumen: New insights on lipolysis with an emphasis on the role of endogenous plant factors. Anim. Feed Sci. Technol. 174:1-25.

Cozzi, G., G. Bittante, and C. E. Polan. 1993. Comparison of fibrous materials as modifiers of in-situ ruminal degradation of corn gluten meal. J. Dairy Sci. 76:1106-1113.

Dewhurst, R. J., W. J. Fisher, J. K. S. Tweed, and R. J. Wilkins. 2003. Comparison of grass and legume silages for milk production. 1. Production response with different levels of concentrate. J. Dairy Sci. 86:2598-2611.

Dewhurst, R. J., N. D. Scollan, S. J. Youell, J. K. S. Tweed, and M. O. Humphreys. 2001. Influence of species, cutting date and cutting interval on the fatty acid composition of grasses. Grass Forage Sci. 56:68-74.

Dierking, R. M. 2008. Fatty acid variation between forage species and within populations and fatty acid content of beef finished on pasture with different forage species. MSc Thesis, Univ. Missouri, Columbia.

Faichney, G. J. 1975. The use of markers to partition digestion within the gastro-intestinal tract of ruminants. In: I. W. McDonald and A. C. O. Warner, editors, Digestion and metabolism in the ruminant. Univ. New England Publishing Unit, Armidale, Australia. p. 277-291.

Halmemies-Beauchet-Filleau, A., A. Vanhatalo, V. Toivonen, T. Heikkilä, M. R. F. Lee, and K. J. Shingfield. 2013. Effect of replacing grass silage with red clover silage on ruminal lipid metabolism in lactating cows fed diets containing a 60:40 forage-to-concentrate ratio. J. Dairy Sci. 96:5882-5900.

Halmemies-Beauchet-Filleau, A., A. Vanhatalo, V. Toivonen, T. Heikkilä, M. R. F. Lee, and K. J. Shingfield. 2014. Effect of replacing grass silage with red clover silage on nutrient digestion, nitrogen metabolism, and milk fat composition in lactating cows fed diets containing 60:40 forage-to-concentrate ratio. J. Dairy Sci. 97:3761-3776.

Harrison, J. H., R. Blauwiekel, and M. R. Stokes. 1994. Fermentation and utilization of grass silage. J. Dairy Sci. 77:3209-3235.
Huhtanen, P., S. Ahvenjarvi, G. A. Broderick, S. M. Reynal, and K. J. Shingfield. 2010. Quantifying ruminal digestion of organic matter and neutral detergent fiber using the omasal sampling technique in cattle - A meta-analysis. J. Dairy Sci. 93:3203-3215.

Hume, I. D., R. J. Moir, and M. Somers. 1970. Synthesis of microbial protein in the rumen. I. Influence of the level of nitrogen intake. Aust. J. Agric. Res. 21:283-296.

Huws, S. A., M. R. F. Lee, S. M. Muetzel, M. B. Scott, and R. J. Wallace. 2010. Forage type and fish oil causes shifts in rumen bacterial diversity. FEMS Microbiol. Ecol. 73:396-407.

Hvelplund, T. 1986. The influence of diet on nitrogen and amino acid content of mixed rumen bacteria. Acta Agric. Scand. 36:325-331.

Jarrett, I. G. 1948. The production of rumen and abomasal fistulae in sheep. J. C. S. I. R. (Aust.) 21:311-315.

Jones, B. A., R. D. Hatfield, and R. E. Muck. 1995. Screening clover forages for soluble phenols, polyphenol oxidase and extract browning. J. Sci. Food Agric. 67:109-112.

Kammes, K. L., and M. S. Allen. 2012. Nutrient demand interacts with forage family to affect digestion responses in dairy cows. J. Dairy Sci. 95:3269-3287.

Kramer, J. K. G., and J. Zhou. 2001. Conjugated linoleic acid and octadecenoic acids: Extraction and isolation of lipids. Eur. J. Lipid Sci. Technol. 103:600-609.

Kuoppala, K., S. Ahvenjärvi, M. Rinne, and A. Vanhatalo. 2009. Effects of feeding grass or red clover silage cut at two maturity stages in dairy cows. 2. Dry matter intake and cell wall digestion kinetics. J. Dairy Sci. 92:5634-5644.

Lee, M. R. F., A. Cabiddu, F. Hou, V. Niderkorn, E. J. Kim, R. Fychan, and N. D. Scollan. 2011. In vitro simulated (RUSITEC) metabolism of freshly cut or wilted grasses with contrasting polyphenol oxidase activities. Grass Forage Sci. 66:196-205.

Lee, M. R. F., P. L. Connelly, J. K. S. Tweed, R. J. Dewhurst, R. J. Merry, and N. D. Scollan. 2006a. Effects of high-sugar ryegrass silage and mixtures with red clover silage on ruminant digestion. 2. Lipids. J. Anim. Sci. 84:3061-3070.

Lee, M. R. F., L. J. Harris, R. J. Dewhurst, R. J. Merry, and N. D. Scollan. 2003. The effect of clover silages on long chain fatty acid rumen transformations and digestion in beef steers. Anim. Sci. 76:491-501.

Lee, M. R. F., L. J. Harris, J. M. Moorby, M. O. Humphreys, M. K. Theodorou, J. C. MacRae, and N. D. Scollan. 2002. Rumen metabolism and nitrogen flow to the small intestine in steers offered Lolium perenne containing different levels of watersoluble carbohydrate. Anim. Sci. 74:587-596.

Lee, M. R. F., J. de J. Olmos Colmenero, A. L. Winters, N. D. Scollan, and F. R. Minchin. 2006b. Polyphenol oxidase activity in grass and its effect on plant-mediated lipolysis and proteolysis of Dactylis glomerata (cocksfoot) in a simulated rumen environment. J. Sci. Food Agric. 86:1503-1511.

Lee, M. R. F., J. K. S. Tweed, A. Cookson, and M. L. Sullivan. 2010. Immunogold labelling to localise polyphenol oxidase (PPO) during wilting of red clover leaf tissue and the effect of removing cellular matrices on PPO protection of glycerol-based lipid in the rumen. J. Sci. Food Agric. 90:503-510.

Lee, M. R. F., J. K. S. Tweed, A. P. Moloney, and N. D. Scollan. 2005. The effects of fish oil supplementation on rumen metabolism and the biohydrogenation unsaturated fatty acids in beef steers fed diets containing sunflower oil. Anim. Sci. 80:361-367.

Lee, M. R. F., J. K. S. Tweed, and M. L. Sullivan. 2013. Oxidation of ortho-diphenols in red clover with and without polyphenol oxidase (PPO) activity and their role in PPO activation and inactivation. Grass Forage Sci. 68:83-92. 
Lee, M. R. F., A. L. Winters, N. D. Scollan, R. J. Dewhurst, M. K. Theodorou, and F. R. Minchin. 2004. Plant-mediated lipolysis and proteolysis in red clover with different polyphenol oxidase activities. J. Sci. Food Agric. 84:1639-1645.

Marita, J. M., R. D. Hatfield, and G. Brink. 2010. In vitro proteolytic inhibition, polyphenol oxidase activity, and soluble o-diphenols in grasses and cereals. J. Agric. Food Chem. 58:959-966.

Mayer, A. M. 2006. Polyphenol oxidases in plants and fungi: Going places? A review. Phytochemistry 67:2318-2331.

McIlvaine, T. C. 1921. A buffer solution for colorimetric comparison. J. Biol. Chem. 49:183-186.

Merry, R. J., M. R. F. Lee, D. R. Davies, R. J. Dewhurst, J. M. Moorby, N. D. Scollan, and M. K. Theodorou. 2006. Effects of highsugar ryegrass silage and mixtures with red clover silage on ruminant digestion. 1. In vitro and in vivo studies of nitrogen utilization. J. Anim. Sci. 84:3049-3060.

Parveen, I., M. D. Threadgill, J. M. Moorby, and A. Winters. 2010. Oxidative phenols in forage crops containing polyphenol oxidase enzymes. J. Agric. Food Chem. 58:1371-1382.

Patton, S., and A. A. Benson. 1966. Phytol metabolism in the bovine. Biochim. Biophys. Acta 125:22-32.

Robert, C. M., F. R. Cadet, C. C. Rouch, M. Pabion, and F. RichardForget. 1995. Kinetic study of the irreversible thermal deactivation of palmito (Acanthophoenix rubra) polyphenol oxidase and effect of pH. J. Agric. Food Chem. 43:1143-1150.

Sukhija, P. S., and D. L. Palmquist. 1988. Rapid method for determination of total fatty acid content and composition of feedstuffs and feces. J. Agric. Food Chem. 36:1202-1206.

Sullivan, M. L., R. D. Hatfield, S. L. Thoma, and D. A. Samac. 2004. Cloning and characterisation of red clover polyphenol oxidase cDNAs and expression of active protein in Escherichia coli and alfalfa. Plant Physiol. 136:3234-3244.

Thomas, T. A. 1977. An automated procedure for the determination of soluble carbohydrates in herbage. J. Sci. Food Agric. 28:639-642.
Vanhatalo, A., P. Huhtanen, V. Toivonen, and T. Varvikko. 1999. Response of dairy cows fed grass silage to abomasal infusions of histidine alone or in combination with methionine and lysine. J. Dairy Sci. 82:2674-2685.

Vanhatalo, A., K. Kuoppala, S. Ahvenjärvi, and M. Rinne. 2009. Effects of feeding grass or red clover silage cut at two maturity stages in dairy cows. 1. Nitrogen metabolism and supply of amino acids. J. Dairy Sci. 92:5620-5633.

Van Ranst, G., M. R. F. Lee, and V. Fievez. 2011. Red clover polyphenol oxidase and lipid metabolism. Animal 5:512:521.

Van Soest, P. J., J. B. Robertson, and B. A. Lewis. 1991. Methods for dietary firer, neutral detergent fiber and non-starch polysaccharides in relation to animal nutrition. J. Dairy Sci. 74:3583-3597.

Van Soest, P. J., and R. H. Wine. 1967. Use of detergents in the analysis of fibrous feeds. IV. Determination of plant cell wall constituents. J. - Assoc. Off. Anal. Chem. 50:50-55.

Vlaeminck, B., V. Fievez, A. R. J. Cabrita, A. J. M. Fonseca, and R. J. Dewhurst. 2006. Factors affecting odd- and branchedchain fatty acids in milk: A review. Anim. Feed Sci. Technol. 131:389-417.

Williams, C. H., D. J. David, and O. Iismaa. 1962. The determination of chromic oxide in faeces samples by atomic absorption spectrophotometry. J. Agric. Sci. 59:381-385.

Wilson, R. F., and J. M. A. Tilley. 1965. Amino-acid composition of Lucerne and of Lucerne and grass protein preparations. J. Sci. Food Agric. 16:173-178.

Winters, A. L., and F. R. Minchin. 2001. Red clover and the future for pasture legumes as an alternative protein source for ruminants. IGER Innov. 5:30-33.

Winters, A. L., and F. R. Minchin. 2005. Modification of the Lowry assay to measure protein and phenols in covalently bonded complexes. Anal. Biochem. 346:43-48.

Zhu, W. Y., M. K. Theodorou, A. C. Longlands, B. B. Nielson, J. Dijkstra, and A. P. J. Trinici. 1996. Growth and survival of anaerobic fungi in batch culture and continuous culture. Anaerobe 2:29-37. 